\title{
IMPLEMENTASI GROUP INVESTIGATION REPORT \\ SEBAGAI ALTERNATIF DALAM PEMBELAJARAN SEJARAH \\ BERBASIS CHARACTER BUILDING \\ DI UNIVERSITAS NEGERI YOGYAKARTA \\ Oleh:
}

Wahyu Setyaningsih, Waidkha Yuliati, Margareta H. Yuliana 1

\begin{abstract}
Abstrak
Penelitian ini bertujuan untuk mengungkapkan penerapan metode group investigasi report dalam pembelajaran sejarah di Universitas Negeri Yogyakarta. Hal ini berangkat dari banyaknya permasalahan dalam pembelajaran sejarah seperti tidak optimalnya penanaman nilai-nilai, dan tidak bervariasinya metode pembelajaran yang biasa digunakan oleh pengajar.

Penelitian dilakukan dengan metode campuran kualitatif-kuantitatif yang dilakukan di beberapa museum antara lain: Benteng Vredeburg, Kraton Yogyakarta, Monumen Yogya Kembali, dan Museum Perjuangan yang dilakukan mulai Februari sampai April 2011. Teknik sampling yang digunakan adalah random sampling dengan jumlah populasi 74 mahasiswa.

Hasil penelitian menunjukkan bahwa dari perhitungan t tabel 7. $294>1$. 691. Ini berarti bahwa hipotesis nol ditolak dan hipotesis awal diterima. Terdapat perbedaan yang signifikan dalam karakter mahasiswa yang menggunakan metode group investigasi dengan yang tidak yaitu 2008-2010.

Kata kunci: tim investigasi report, pembangunan karakter, pembelajaran sejarah.
\end{abstract}

\section{Abstract}

This research was aimed to find out the application of the group investigative report on history lesson.The problems of history lesson were inculcation of value for students who were less optimal, and there was no variation on learning method was uses by educators.

Research conducted uses mixture approach both qualitative and quantitative method.It conducted in some museum such as: Benteng Vredenburg, Kraton Yogyakarta, Monumen Yogya Kembali, and Perjuangan museum on February to April 2011.The Sample of research determined by random sampling system with population 74.

The results shows that calculate> ttables t7.294> 1.691.Itmeans that the null hypothesis (Ho) was rejected, and the final hypothesis ( $\mathrm{Ha}$ ) accepted.There isa significant difference in character between 2008-2010 that forced students to use methods Investigation Group Report by not using the method Investigation Team Report.

Key words: Investigation Team Report, character building, history learning. 
A. Pendahuluan

Globalisasi merupakan keran perubahan zaman. Informasi dan teknologi mampu menjadi jaminan untuk mampu bertahan dalam era yang serba tanpa batas baik ruang dan waktu. Berbagai indentitas dan jati diri dari setiap bangsa pun dapat hilang tak berbekas bak mengukir di atas air manakala generasi muda dihadapkan pada berbagai hal baru yang lebih menarik dan mereka acuh dengan warisan yang telah ada. Bagitu pun dengan generasi muda Indonesia, terutama para mahasiswa sebagai generasi ilmiah yang punya kelebihan jika tidak peduli dengan kebinekaan maka kehancuran identitas Indonesia di depan mata.

Keadaan ekonomi yang semakin sulit menyebabkan manusia menggunkan cara pintas untuk memperoleh penghasilan tanpa mendengarkan nurani dan berakibat untuk orang lain. Korupsi merupakan kasus yang sedang menjadi primadona di Indonesia, tidak hanya di satu instansi pemerintahan, tetapi di berberapa instansi pun kasus ini tidak dapat dihindarkan. Maka tidak heran jika Indonesia mendapat sebutan sebagai Negara muslim terbanyak dan terkorup di dunia. Hal ini sangat ironis sekali sehingga diperlukan upaya pembenahan karakter secepatnya dari hal yang sangat urgent sampai hal-hal yang mendukungnya dari berbagai kalangan.

Degradasi mental, moral, budi pekerti, sopan santun dan lain sebagainya merupakan ancaman bagi masa depan bangsa Indonesia. Sikap hedonis, pragmatif dan ikut-ikutan mampu melunturkan nilai-nilai luhur bangsa Indonesia. Hal ini menunjukan masih lemahnya karakter bangsa dewasa ini sehingga menyebabkan kepemimpinan, manajemen dan perilaku yang kurang memberikan keberhasilan dalam pencapaian tujuan nasional.

Menurut Lickona (1991) ka-rakter merupakan konsep psikologis yang kompleks, tidak hanya terdiri dari satu domain saja, namun harus menyentuh semua domain secara lengkap, yaitu kognitif, afeksi dan psikomotor. 2 Sedangkan menurut Jacoeb Ezra karakter adalah kekuatan untuk bertahan dimasa sulit. Karekter tidak dapat diciptakan, tetapi karakter dapat dibentuk melalui temparamen dasar (dominance, steadiness, influence, compliance), keyakinan, pendidikan. motivasi hidup dan pengalaman hidup. Maka character building adalah proses membentuk manusia yang unggul dan adaptif tanpa bertentangan dengan etika dan moralitas sehingga mampu bermanfaat bagi orang lain.

Sejarah menyadarkan kepada kita akan siapa diri kita. Sejarah bukanlah sekedar rangkaian peristiwa masa lampau yang tanpa makna, tetapi peristiwa yang tidak terlepas dari masa kini dan masa depan. Menurut Sartono Kartodirjo sejarah nasional sebagai tuangan pengalaman kolektif

Lickona, Thomas, Educating for Character: How Our School Can Teach Respect and Responsibility. New York, Toronto, 
bangsa merupakan karakteristik pokok bagi bangsa yang bersangkutan. Hal ini menunjukan bahwa identitas kolektif menunjukan kepada kepribadian nasional. Maka kesadaran sejarah akan memperkokoh eksistensi dan identitas serta kepribadian suatu bangsa untuk mewujudkan character building national melalui rasa bangga akan sejarah dan kebudayaan bangsa Indonesia sehingga warisan nilai-nilai luhur budaya bangsa tetap lestari.

Sejarah mempunyai kekuatankekuatan yang tidak dapat terlepas dari kehidupan manusia. Menurut Carl G. Gustavson bahwa kekuatan sejarah terdiri dari ekonomi, agama, institusi (politik), teknologi, ideology dan militer. Pada perkembangan selanjutnya kekuatan sejarah bertambah menjadi individu, seks, umur, mitos, golongan, etnis dan ras serta budaya. Hal ini memberikan makna bahwa sejarah mampu merubah kehidupan, karena kekuatan-kekuatan tersebut mampu menentukan jalannya peristiwa baik ketika kekuatan -kekuatan itu berjalan sendiri atau kekuatan-kekuatan berjalan bersamaan maka dapat menjadi sebuah revolusi.

Dewasa ini pembelajaran sejarah masih berorientasi pada fakta. Nilainilai yang terdapat dalam setiap peristiwa sejarah belum secara optimal tertuang dalam proses pembelajaran. Mahasiswa hanya ditekankan pada texsbook oriented. Seperti yang diungkapkan oleh Hamid Hasan dalam Alfian (2007) bahwa kenyataan yang ada sekarang, pembelajaran sejarah cenderung hanya memanfaatkan fakta sejarah sebagai materi utama. Tidak aneh bila pendidikan sejarah terasa kering, tidak menarik, dan tidak memberi kesempatan kepada peserta didik untuk belajar menggali makna dari sebuah peristiwa sejarah sehingga pembelajaran sejarah jauh dari harapan untuk memungkinkan mahasiswa melihat relevansinya dengan kehidupan masa kini dan masa depan.

Pembelajaran sejarah masih dianggap hal yang membosankan. Pada umumnya metode yang digunakan dalam kegiatan pembelajaran adalah ceramah. Model-model pembelajaran yang ada belum banyak dilakukan dalam pembelajaran sejarah. Hal ini juga dipengaruhi oleh berbagai faktor seperti profesionlisme pendidik, fasilitas yang dan sebagainya. Padahal pembelajaran sejarah merupakan sarana strategis dalam merealisasikan pembentukan karakter (character building ). Melalui studi kritis yang dimiliki sejarah mampu membentuk pola pikir untuk mampu berfikir kritis terhadap berbagai keputusan yang akan diambilnya. Oleh karena itu diperlukan metode yang mampu merelisasikannya sehingga para peserta didik menjadi insane yang cerdas, humanis dan kritis tanpa mengesampingkan sejarah bangsa.

Group Investigation Report merupakan salah satu metode strategis dalam mencapai tujuan pembelajaran sejarah yakni untuk 
menciptakan insan yang berkarakter. Metode ini lahir dari hasil pemikiran Dewey mengenai konsep pendidikan bahwa kelas seharusnya merupakan cermin masyarakat dan berfungsi sebagai laboratorium untuk belajar tentang kehidupan nyata. Pemikiran Dewey yang utama tentang pendidikan adalah: (1) siswa hendaknya aktif: learning by doing; (2) belajar hendaknya didasari motivasi intrinsik; (3) pengetahuan berkembang, tidak bersifat tetap; (4) kegiatan belajar hendaknya sesuai dengan kebutuhan dan minat siswa; (5) pendidikan harus mencakup kegiatan belajar dengan prinsip saling memahami dan saling menghormati satu sama lain: prosedur demokratis sangat penting; (6) kegiatan belajar hendaknya berhubungan dengan dunia nyata.

Penjajahan Belanda identik dengan kekejaman, kesengsaraan dan penderitiaan. Tanam Paksa (cultuure stelsel) terjadi hampir empat puluh tahun mampu membuat Belanda surplus akan keuntungan sehingga mampu menyelamatkan keadaan ekonomi Belanda. Peristiwa ini mampu sebagai pendidikan karakter, seperti mengembangkan sikap empati dan simpati manakala melihat orang lain sedang mengalami penderitaan. Selain itu, karakter pekerja keras perlu ditumbuhkembangkan dalam berbagai bidang kehidupan seharihari untuk memperoleh hasil yang maksimal. Oleh karena itu, dengan pembelajaran sejarah mampu menumbuhkembangkan kecerdasan kog- nitif, afektif dan psikomotorik dalam setiap peristiwa.

Dengan demikian nampak betapa penting posisipembelajaran sejarah dalam rangka character building (pembangunan karakter) di Universitas Negeri Yogyakarta sebagai kampus pendidikan. Pendidikan sejarah sarat dengan pendidikan karakter yang sangat dibutuhkan yakni pendidikan moral, penalaran, politik, kebijakan, perubahan, masa depan, keindahan. Nilai-nilai kepahlawanan, keteladanan, kepeloporan, patriotisme, nasionalisme, dan semangat pantang menyerah yang mendasari proses pembentukan watak dan kepribadian dan ajaran moral dan kearifan yang berguna dalam mengatasi krisis multidimensi yang dihadapi dalam kehidupan sehari -hari serta menanamkan kesadaran persatuan dan persaudaraan serta solidaritas sebagai perekat bangsa dalam menghadapi ancaman disintegrasi bangsa.

Dari permasalahan diatas maka diperlukan upaya mencari sebuah solusi untuk memperbaiki pola pembelajaran sejarah yang belum menekankan pada nilai-nilai di balik peristiwa sejarah. Solusi ter-sebut adalah dengan melakukan upaya melalui pengotimalan metode group investigation report atau melaporkan hasil pengamatan dari setiap kelompok terhadap setiap peristiwa sehingga terjadi relevansi dari pembelajaran sejarah dalam kehidupan tanpa harus mengesampingkan kreativitas peserta didik. 
Berdasarkan latar belakang masalah di atas, permasalahan dalam penelitian ini adalah Bagaimanakah implementasi group investigation report dalam pembelajaran sejarah untuk meningkatkan character building mahasiswa Pendidikan Sejarah UNY? Adapun hipotesisnya adalah Group Investigation Report dapat digunakan sebagai alternative dalam pembelajaran sejarah berbasis character building di Universitas Negeri Yogyakarta. Tujuan penelitian adalah mengetahui implementasi dari group investigation report dalam pembelajaran sejarah untuk meningkatkan character building mahasiswa Pendidikan Sejarah UNY.

Keguanaan penelitian ini ada-lah sebagai solusi alternative dalam character building mahasiswa melalui penerapan Group Investigation Report dalam pembelajaran sejarah. Kegunaan bagi mahasiswa dan masyarakat adalah dapat dijadikan sebagai referensi bagi penelitian berikutnya dan mengaplikasikan ilmu yang diperoleh untuk dikembangkan dan bermanfaat bagi masyarakat umum.

\section{B. Group Investigation Report}

Santyasa mengungkapkan pembelajaran kooperatif tipe GI didasari oleh gagasan John Dewey tentang pendidikan, bahwa kelas merupakan cermin masyarakat dan berfungsi sebagai laboratorium untuk belajar tentang kehidupan di dunia nyata yang bertujuan mengkaji masalah-masalah sosial dan antar pribadi. Pada pembelajaran ini guru seyogyanya mengarahkan, membantu para siswa menemukan informasi, dan berperan sebagai salah satu sumber belajar, yang mampu menciptakan lingkungan sosial yang dicirikan oleh lingkungan demokrasi dan proses ilmiah. 3

Pembelajaran kooperatif tipe GI, guru membagi kelas menjadi kelompok-kelompok dengan anggota 5 atau 6 siswa heterogen dengan mempertimbangkan keakraban dan minat yang sama dalam topik tertentu. Siswa memilih sendiri topik yang akan dipelajari, dan kelompok merumuskan penyelidikan dan menyepakati pembagian kerja untuk menangani konsep-konsep penyelidikan yang telah dirumuskan. Dalam diskusi kelas ini diutamakan keterlibatan pertukaran pemikiran para siswa. Jadi group investigation report adalah model pembelajaran yang dirancang untuk membimbing para siswa mendefinisikan masalah, mengeksplorasi berbagai cakrawala mengenai masalah itu, mengumpulkan data yang relevan, mengembangkan dan mengetes hipotesis.

Menurut Slavin (Asthika, 2005:24) bahwa tahapan-tahapan dalam pembelajaran group invest-tigation report yaitu (1) grouping (menetapkan jumlah anggota kelompok, menentukan sumber, memilih topik, merumuskan permasalahan), (2) planning (menetapkan apa yang akan dipelajari, bagaimana

3 Depdiknas, Undang-Undang Guru dan Dosen, 
mempelajari, siapa melakukan apa, apa tujuannya), (3) investigation (saling tukar informasi dan ide, berdiskusi, klarifikasi, mengumpulkan informasi, menganalisis data, membuat inferensi), (4) organizing (anggota kelompok menulis laporan, merencanakan presentasi laporan, penentuan penyaji, moderator, dan notulis), (5) presenting (salah satu kelompok menyajikan, kelompok lain mengamati, mengevaluasi, mengklarifikasi, mengajukan pertanyaan atau tanggapan), dan (6) evaluating (masing-masing siswa melakukan koreksi terhadap laporan masingmasing berdasarkan hasil diskusi kelas, siswa dan guru berkolaborasi mengevaluasi pembelajaran yang dilakukan, melakukan penilaian hasil belajar yang difokuskan pada pencapaian pemahaman. 4

C. Pembelajaran Sejarah

Menurut Hamid Hasan dan Alfian (2007) bahwa dewasa ini pembelajaran sejarah jauh dari harapan untuk memungkinkan anak melihat relevansinya dengan kehidupan masa kini dan masa depan. Mulai dari jenjang SD hingga SMA, pembelajaran sejarah cenderung hanya memanfaatkan fakta sejarah sebagai materi utama. Tidak aneh bila pendidikan sejarah terasa kering, tidak menarik, dan tidak memberi kesempatan kepada anak didik untuk belajar menggali makna dari sebuah 4

Anonim. 2009.Tips Pengembangan Diri Dinamika Berpikir Positif.Diakses pada: hari Sabtu, 21 Agustus 2010 Pukul 07:39 wib. Sumber: http://produser eksekutif.blogspot.com/2009/06/tips- peristiwa sejarah. Taufik Abdullah memberi penilaian, bahwa strategi pedagogis sejarah Indonesia sangat lemah. Pendidikan sejarah di sekolah masih berkutat pada pendekatan chronicle dan cenderung menuntut anak agar menghafal suatu peristiwa. Siswa tidak dibiasakan untuk mengartikan suatu peristiwa guna memahami dinamika suatu perubahan.

Sistem pembelajaran sejarah yang dikembangkan masih menggunakan model pembelajaran yang bersifat satu arah dimana guru menjadi sumber pengetahuan utama dalam kegiatan pembelajaran. Hal ini mengakibatkan peran siswa sebagai pelaku sejarah pada zamannya menjadi terabaikan. Pengalaman-pengalaman yang telah dimiliki oleh siswa sebelumnya atau lingkungan sosialnya tidak dijadikan bahan pelajaran di kelas, sehingga menempatkan siswa sebagai peserta pembelajaran sejarah yang pasif. Dengan kata lain, kekurangcermatan pemilihan strategi mengajar akan berakibat fatal bagi pencapaian tujuan pengajaran itu sendiri.

\section{Pengertian Character}

Akar kata karakter dapat dilacak dari kata Latin kharakter, kharassein, dan kharax, yang maknanya "tools for marking ", "to engrave", dan "pointed stake". Pada abad ke -XIV kata ini mulai banyak digunakan (kembali) dalam bahasa Perancis caractere dan kemudian masuk dalam bahasa Inggris menjadi character, sebelum akhirnya menjadi karakter dalam bahasa Indonesia. 
Dalam Kamus Poerwadar-minta, karakter diartikan sebagai tabiat, watak, sifat-sifat kejiwaan, akhlak atau budi pekerti yang membedakan seseorang daripada yang lain. Dengan pengertian di atas dapat dikatakan bahwa membangun karakter (character building) adalah proses mengukir atau memahat jiwa sedemikian rupa, sehingga 'berbentuk' unik, menarik, dan berbeda atau dapat dibedakan dengan orang lain. Ibarat sebuah huruf dalam alfabet yang tak pernah sama antara yang satu dengan yang lain, demikianlah orang-orang yang berkarakter dapat dibedakan satu dengan yang lainnya (termasuk dengan yang tidak atau belum berkarakter atau 'berkarakter' tercela).

Karakter memang sulit didefinisikan, tetapi lebih mudah ditangkap melalui adanya uraian (describe) berisikan pengertian. Karakter menurut Sigmund Freud adalah Character is astriving system which underly behaviour, yang dapat diartikan sebagai kumpulan tata nilai yang mewujud dalam suatu sistem daya dorong (daya juang) yang melandasi pemikiran, sikap dan perilaku, yang akan ditampilkan secara mantap. Karakter merupakan aktualisasi potensi dari dalam dan internalisasi nilai-nilai moral dari luar menjadi bagian kepribadiannya.

Karakter merupakan nilai-nilai yang terpatri dalam diri kita melalui pendidikan, pengalaman, percobaan, pengorbanan dan pengaruh lingkungan, menjadi nilai intrinsik yang melandasi sikap dan perilaku kita. Jadi, karena karakter harus diwujudkan melalui nilai-nilai moral yang dipatrikan untuk menjadi semacam nilai intrinsik dalam diri kita, yang akan melandasi sikap dan perilaku kita, tentu karakter tidak datang dengan sendirinya, melainkan harus kita bentuk, kita tumbuh kembangkan dan kita bangun.

1. Unsur-unsur

Character Building

Unsur terpenting dalam pembentukan karakter adalah pikiran, karena pikiran yang di dalamnya terdapat seluruh program yang terbentuk dari pengalaman hidupnya, merupakan pelopor segalanya. Program ini kemudian membentuk sistem kepercayaan yang akhirnya dapat membentuk pola berpikirnya yang bisa mempengaruhi perilakunya. Oleh karena itu, pikiran harus mendapatkan perhatian serius. Tentang pikiran, Joseph Murphy mengatakan bahwa di dalam diri manusia terdapat satu pikiran yang memiliki ciri yang berbeda. Untuk membedakan ciri tersebut, maka istilahnya dinamakan dengan pikiran sadar (conscious mind) atau pikiran objektif dan pikiran bawah sadar (subconscious mind) atau pikiran subjektif. (Joseph Murphy, $\quad$ 2002: 6).

Pikiran sadar secara fisik terletak di bagian korteks otak bersifat logis dan analisis dengan memiliki pengaruh sebesar $12 \%$ 
dari kemampuan otak. Sedangkan pikiran bawah sadar secara fisik terletak di medulla oblongata yang sudah terbentuk ketika masih di dalam kandungan. Pikiran sadar (conscious) adalah pikiran objektif yang berhubungan dengan objek luar dengan menggunakan panca indra sebagai media dan sifat pikiran sadar ini adalah menalar. Pikiran bawah sadar (subsconscious) adalah pikiran subjektif yang berisi emosi serta memori, bersifat irasional, tidak menalar, dan tidak dapat membantah. Kerja pikiran bawah sadar menurut Gunawan dan Setyono (2006) menjadi sangat optimal ketika kerja pikiran sadar semakin minimal.

Konsep dari tokoh bernama Abraham Maslow yang menyatakan bahwa studi tentang orangorang yang mengaktualisasikan dirinya mutlak menjadi fondasi bagi sebuah ilmu psokologis yang lebih semesta. Hal ini digambarkan dengan bagan sebagai berikut.

Kebutuhan untuk aktualisasi diri $\mathrm{V}$

Kebutuhan untuk dihargai $\mathrm{V}$

Kebutuhan untuk dicintai dan disayangi
$\mathrm{V}$
tentram
$\mathrm{V}$

Kebutuhan fisiologis dasar Gambar 1. Hirarkhi kebutuhan Abraham Maslow

(Frank Goble, 1993:34)
$\%$

Keterangan Bagan: Kebutuhan fisiologis dasar: gaji,

* makanan, pakaian, perumahan Kebutuhan akan rasa aman: lingkungan kerja yang bebas dari

* segala bentuk ancaman

Kebutuhan untuk dicintai dan disayangi: kesempatan yang diberikan untuk menjalin hubungan yang akrab dengan

* orang lain

Kebutuhan untuk dihargai: pemberian penghargaan atau reward, mengakui hasil karya

* individu

Kebutuhan aktualisasi diri: kesempatan dan kebebasan untuk merealisasikan cita-cita atau harapan individu

2. Jenis-jenis Character Jenis-jenis Character dibedakan menjadi dua yaitu a) character Positif dan b) character negative. Character positif meliputi 1) Pola Pikir Optimis yaitu cara berpikir atau cara memandang sesuatu dengan optimis dan baik akan menghasilkan kata-kata yang keluar dari mulutnya juga katakata yang positif, kata-kata yg membangun, kata-kata yang optimis dan akan menghasilkan mentalitas seorang fighter dalam artian pribadi unggul yang memiliki daya juang tinggi dalam menghadapi problema atau rintangan. 2) Pola Emosi Stabil yaitu sesorang yang mampu menghadapi situasi-situasi krusial dan bereaksi dengan sikap-sikap yang baik dengan ketenangan 
dalam menghadapi rintanganrintangan atau masalah, sehingga memampukan pribadi tersebut melihat suatu masalah dengan obyektif dan mencari-cari solusi yang baik dan tidak terseret atas emosi sesaat. 3) Pola Tingkah Laku merupakan hasil dari pola pikir dan pola emosi.

Character Negatif meliputi a) pesimis atau rendah diri adalah tidak percaya diri menghadapi masalah-masalah atau rintanganrintangan yang datang menghadang. b) skeptis dalam memandang atau menanggapi sesuatu yaitu menanggapi peluang atau kesempatan atau informasi dengan penolakan (skeptis), tanpa dianalisa atau diuji apakah benar atau tidak langsung ditolak mentah-mentah. c) Excuse yaitu selalu beralasan jika disuruh untuk mengerjakan sesuatu atau pun ditawari suatu kesempatan yang mungkin bisa membawa ke arah yg lebih baik atau sukses. c) Citra diri yang Salah adalah merasa diri kurang mampu, merasa bahwa diri tidak pintar, bukan dari golongan orang kaya, atau berbagai alasan lainnya. d) Mudah Menyerah adalah kurang berani dalam menghadapi resiko atau tantangan bila ada sedikit goncangan saja maka akan undur diri.

Dalam kehidupan $\begin{aligned} & \text { suatu } \\ & \text { karakter yang menempel } \\ & \text { dalam }\end{aligned}$
pribadi manusia adalah sangat
penting. Peran karakter bagi diri

seorang manusia adalah ibarat kemudi bagi sebuah kapal, karakter adalah kemudi hidup yang akan menentukan arah yang benar dalam bahtera kehidupan seorang manusia.Pada dasarnya kepribadian dari diri seseorang merupakan suatu cerminan dari kesuksesan. Seseorang yang mempunyai kepribadian yang unggul adalah seseorang yang siap untuk hidup dalam kesuksesan. Sebab dalam kepribadian orang tersebut terdapat nilai-nilai positif.

\section{E. Hasil Dan Pembahasan}

1. Hasil Anaslisi Kuantitatif

Hasil perhitungan deng-an menggunakan SPSS 15 pada data sebelum perlakuan pada kelas eksperimen didapatkan jumlah sampel yang valid $=18$; skor rata-rata $($ Mean $)=80.222$; nilai tengah $($ median $)=81.00$; simpangan baku (standard deviation) $=6.11224$; varian (variance $)=37.359$; kemencengan (skewness) = -0.359; skor minimum $=68$; skor maksimum = 90. Jadi karakterisik skor mahasiswa kelas eksperimen sebelum perlakuan adalah rata-rata 56.25 (skor minimum 0 dan skor maksimum 10).

$\begin{array}{ccc}\text { Pada } & \text { kelas } & \text { kontrol } \\ \text { diperoleh } & \text { data } & \text { sebelum } \\ \text { perlakuan didapatkan } & \text { jumlah }\end{array}$




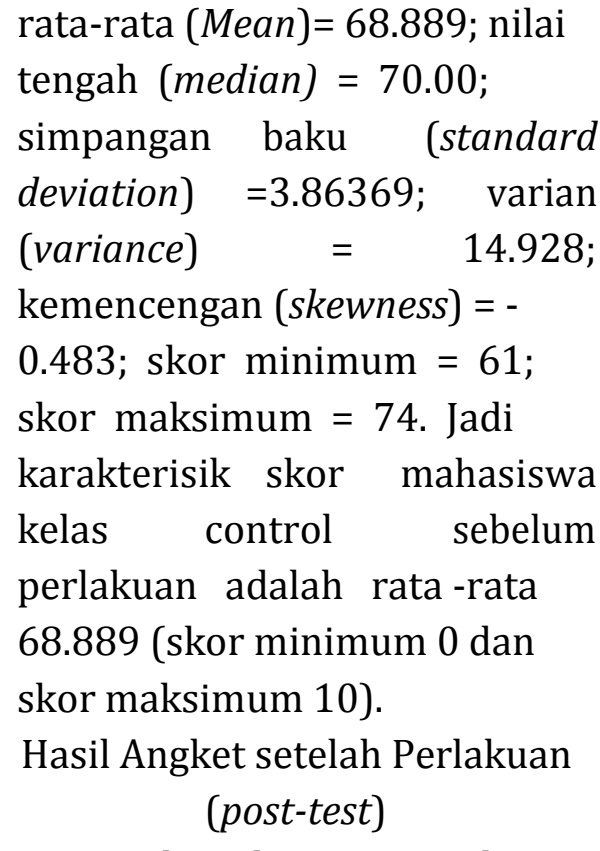

Hasil perhitungan dengan menggunakan SPSS 15 pada data setelah perlakuan pada kelas eksperimen didapatkan jumlah sampel yang valid = 18; skor rata-rata $($ Mean $)=85.889$; nilai tengah (median) $=86.500$; simpangan baku (standard deviation $)=5.64529 ; \quad$ varian (variance $) \quad=31.8699 ;$ kemencengan (skewness) = 0.938; skor minimum $=70$; skor maksimum $=97$. Jadi karakterisik skor mahasiswa kelas eksperimen sebelum perlakuan adalah rata -rata 86.889 (skor minimum 0 dan skor maksimum 10).

\begin{tabular}{|c|c|c|}
\hline $\begin{array}{l}\text { Pada } \\
\text { diperoleh } \\
\text { perlakuan } \\
\text { sampel yan } \\
\text { rata-rata ( } N \\
\text { tengah (me } \\
\text { simpangan }\end{array}$ & $\begin{array}{c}\text { kelas } \\
\text { data } \\
\text { lidapatkan } \\
\text { valid = 18; } \\
\text { ean) = 75.94 } \\
\text { dian) = } 76 . \\
\text { baku }\end{array}$ & $\begin{array}{l}\text { kontrol } \\
\text { sebelum } \\
\text { jumlah } \\
\text { skor } \\
44 \text {; nilai } \\
500 \text {; } \\
\text { standard }\end{array}$ \\
\hline viation) & $=1.25895$ & varian \\
\hline
\end{tabular}

(variance $) \quad=\quad 1.585 ;$ kemencengan (skewness) = 0.680 ; skor minimum $=74$; skor maksimum $=77$. Jadi karakterisik skor mahasiswa kelas eksperimen sebelum perlakuan adalah rata-rata 75.944 (skor minimum 0 dan skor maksimum 10).

Dengan demikian karakteristikskor kelas ekperimen jauh lebih besar dari pada kelas kontrol. Hal ini dapat dilihat dari nilai rata-rata antara kelas ekperimen sebesar 86.889 dan kelas kontrol sebesar 75.944. Hasil ini juga menggambarkan karakter-karakter mahasiswa kelas eksperimen jauh lebih berkarakter dari pada kelas kontrol.

Pertanyaan-pertanyaan dari angket dikatakan valid dan reliabel. Hal ini berdasarakan konsultasi antara dosen pembimbing dan para ahli statistika serta berdasarkan hasil SPSS 15.00.

Sebelum pengujian hipotesis penelitian maka terlebih dahulu dilakukan pengujian prasyarat analisis yang meliputi Uji Normalitas dan Uji Homogenitas. Bila prasyarat uji analisis tersebut terpenuhi, maka analisis untuk pengujian hipotesis penelitian dengan Uji-t dapat dilakukan.

Uji Normalitas ini dilakukan untuk mengetahui apakah data hasil penelitian 
berdistribusi normal atau tidaknya. Uji Normalitas dilakukan pada data kemampuan awal (pre-test) dan data kemampuan akhir (post-test), baik pada kelas eksperimen maupun kelas kontrol. Uji normalitas menggunakan rumus Chi Kuadrat dengan menggunakan program SPSS 15.00. Hasil perhitungan yang diperoleh dapat dilihat pada tabel 8 sebagai berikut.

Rangkuman Hasil Uji

Normalitas

Tabel 5 menunjukkan bahwa $\quad 2$ xhinng untuk semua data variabel lebih besar dari 2 pada taraf signifikansi 5\%. Hal ini menunjukkan bahwa sebaran data berdistribusi normal.

Uji Homogenitas dimaksudkan untuk mengetahui apakah sebaran data variabel homogen atau tidak. Uji Homogenitas dihitung dengan menggunakan Independen Sample Test Program SPSS 15.00. Hasil Uji

Homogenitas sebaran data variabel dapat dilihat pada tabel berikut.

Hasil Uji Homogenitas

Berdasarkan $\begin{gathered}\text { tabel } 9 \\ \text { lebih kecil }\end{gathered}$
terlihat nilai $F$ dft=1 dan
daripada Ftabel, $\quad$ df1
df2=34, pada taraf signifikansi
5\%. Hal ini menunjukkan
bahwa data sebaran yang

diambil sebelum dan sesudah perlakuan adalah homogen. Berdasarkan deskripsi data dan uji prasyarat analisis (Uji Normalitas dan Uji Homogenitas), telah menunjukkan bahwa data berdistribusi normal dan homogen, maka pengujian hipotesis dapat dilakukan. Pengujian hipotesis dilakukan dengan menggunakan Independen Sample Tes. Uji-t digunakan untuk menguji hipotesis nol (Ho) sehingga diketahui Ho diterima atau ditolak.

a. Hipotesis

Ho : "Group Investigation Report tidak dapat digunakan sebagai alternative dalam pembelajaran sejarah berbasis character building di Universitas Negeri Yogyakarta"

Ha : "Group Investigation Report dapat digunakan sebagai alternative dalam pembelajaran sejarah berbasis character building di Universitas Negeri Yogyakarta"

b. Kriteria pengujian

Tolak Ho dan terima Ha bila t hitung > t tabel $5 \%$ Terima Ho dan tolak Ha bila t hitung < t tabel $5 \%$ Hasil Uji-t yang diperoleh dengan menggunakan analisis Indepen- 


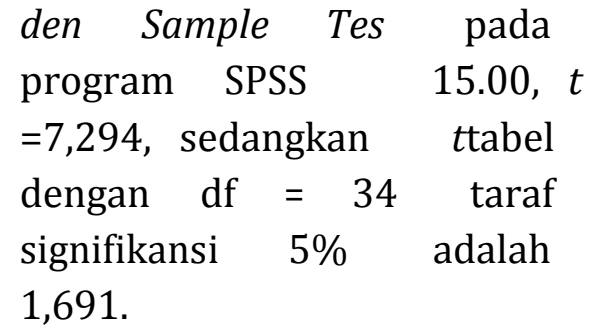

Rangkuman Hasil Uji - $t$

Dari table di atas

diperoleh bahwa thitung $>$ tabel

yaitu 7,294> 1,691. Hasil ini

berarti hipotesis nol (Ho) ditolak, dan hipotesis akhir

(Ha) diterima. Jadi Group Investigation Report dapat digunakan sebagai alternative dalam pembelajaran sejarah berbasis character building di Universitas Negeri Yogyakarta

2. Pelaksanaan Metode Group Investigation Report dalam Pembelajaran Sejarah

Pelaksanaan metode GIR merupakan salah satu metode untuk meningkatkan daya tarik mahasiswa dan mengembangkan karakter. Dalam tahapan GIR akan terlihat karakter. Tahap grouping terlihat karakter mahasiswa seperti rasa saling menghormati terhadap perbedaan yang ada. Tahap planning terlihat karakter seperti kemandirian, kerjasama, berinteraksi satu sama lain, berdiskusi dan menghargai perbedaan pendapat. Tahap investigation terlihat karakter mahasiswa jawab, saling mengahargai, menatati peraturan, menjaga kebersihan, jiwa nasionalisme, patriotisme terhadap peninggalan sejarah. Tahan presenting terlihat karakter seperti kerjasama, saling menghargai pendapat antar individu dalam kelompok. Tahap evaluating terlihat karakter mau menerima pendapat dan tidak egois. Jadi dalam setiap proses dalam tahap GIR menyimpan nilainilai karakter yang dapat diimplementasiakan dalam kehidupan.

Kelebihan dalam GIR adalah mahasiswa mampu mengembangkan karakter positif disamping kemampuan kognitif, afektif dan psikomotorik, memicu individu untuk berpikir lebih kritis dan analitis, pembelajaran lebih berfokus pada student oriented. Kelemahan dalam GIR adalah waktu yang diperlukan relative lebih lama dan biaya yang digunakan relative lebih banyak daripada metode konvensional. Kekurangan ini dapat diatasi dengan GIR dilakukan diakhir proses pembelajaran sebelum ujian, tempat-tempat yang digunakan tidak harus yang mengelurkan dana. Jadi implementasi GIR dapat dijadikan solusi alternative dalam pembelajaran berbasis 
character building di Universitas Negeri Yogyakarta.

3. Perbedaan Karakter Mahasiswa Metode GIR telah banyak memberikan kontribusi terhadap karakter mahasiswa. Hal ini dapat dilihat pada skor rata-rata post-test kelas eksperimen $=85.889$ dan kelas control $=75.944$. Nilai ratarata kelas eksperimen lebih tinggi dari kelas kontrol sebesar 19.945. Dengan mengetahui adanya taraf signifikansi pada table 7 berarti ada perbedaan karakter mahasiswa yang signifikan antara mahasiswa yang menggunakan GIR sebesar $85.889 \%$ sedangkan bagi kelas yang tidak menggunakan GIR sebesar 75.944\%. Hasil tersebut menunjukkan ada

perbedaan sebesar $19.945 \%$ yang diberikan perlakuan dengan kelas tanpa perlakuan. Jadi berdasarkan hasil analisis penelitian, metode GIR dapat menjadi alternative dalam pembelajaran sejarah berbasis character building di Universitas Negeri Yogyakarta

F. Kesimpulan

\begin{tabular}{lrr} 
Group Investigation & Report \\
(GIR) tepat & \multicolumn{2}{c}{ diimplementasikan } \\
sebagai & alternative & dalam \\
pembelajaran & sejarah & berbasis \\
character building di & Universitas
\end{tabular}

dibuktikan dengan adanya perbedaan karakter antara mahasiswa yang menggunakan GIR sebesar $85.889 \%$, sedangkan bagi kelas yang tidak menggunakan GIR sebesar 75.944\%. Hasil tersebut menunjukkan ada perbedaan sebesar $19.945 \%$.

Ketercapaian indikator GIR meliputi kerja sama, tanggung jawab, disiplin dan mandiri. Berdasarkan hasil analisis penelitian, metode GIR dapat menjadi alternative dalam pembelajaran sejarah berbasis character building di Universitas Negeri Yogyakarta.

Salah satu metode pembelajaran untuk menumbuhkan karakter bagi mahasiswa adalah melalui Group Investigation Report sehingga pendidikan karakter tidak hanya sebatas teori saja tetapi diimplementasikan dalam proses pembelajaran.

\section{REFERENSI}

Alicia. 2008. Teori Pembentukan Karakter. Diakses pada: hari Sabtu, 21 Agustus 2010 Pukul 07:39 wib. Sumber: Sumber: skripsi.blogspot.com/2008/07/t eori-pembentukankarakter.html

Anonim. 2009.Tips Pengembangan Diri -Dinamika Berpikir Positif. Agustus 2010 Pukul 07:39 wib. Sumber: http://produser eksekutif.blogspot.com/2009/0 6/tips-pengembangan-diri- 
Djajendra. 2010. Kembangkan Karakter Positif Anda.Diakses pada: hari Sabtu, 21 Agustus 2010 Pukul 07:39 wib. Sumber: http://kecerdasanmotivasi.wor dpress.com/2010/08/13/kemb angkan-karakter-positif-anda/

Hanwie. 2008. Karakter Positif dan Karakter Negatif.Diakses pada: hari Sabtu, 21 Agustus 2010 Pukul 07:39 wib. Sumber: http://www.jawaban.com/index .php/forum/detail/cat id/5/sub cat id/25/id_news/080524034 032.html

Kartodirdjo, Sartono. 1994. Pembangunan Bangsa tentang Nasionalisme, Kesadaran dan Kebudayaan Nasional. Yogyakarta: Aditya Media.

Koentjaraningrat, 1984. Kebudayaan Mentalitas dan Pembangunan. Cetakan ke-11. Jakarta: Gramedia.

Notosusanto, Nugroho. 1979. Sejarah Demi Masa Kini. Jakarta: UI press.

Safira, Joe. 2010. Aliran Dalam Psikologi dan Pandangan Tentang Karakter Manusia. Diakses pada: hari Sabtu, 21 Agustus 2010 Pukul 07:39 wib. Sumber: Joesafira diakses dari: http://delsajoesafira.blogspot.co

m/2010/05/aliran -dalam-

psikologi-dan-pandangan.html.
Sedyawati, Edi. 2006a. "Tentang Sumberdaya

Budaya", Sabda: Jurnal Kajian Kebudayaan, Volume 1, Nomor 2, Desember 2006. Semarang: Fakultas Sastra Universitas Diponegoro

Sedyawati, Edi. 2007. Keindonesiaan dalam Budaya: Buku 1 Kebutuhan Membangun Bangsa yang Kuat. Jakarta: Wedatama Widya Sastra.

Setiadi, Elly M., Kama A. Hakam, Ridwan Effendi. 2007. Ilmu Sosial dan Budaya Dasar. Cetakan ke-2. Jakarta: Kencana Prenada Media Group.

Sevilla, Consuelo, dkk.. 1993. Pengantar Metode Penelitian. Jakarta: UI Press.

Smiers, Joost. 2009. Arts under Pressure: Memperjuangkan Keanekaragaman Budaya di Era Globalisasi. Terjemahan Umi Haryati. Yogyakarta: Insistpress.

Suharsimi Arikunto. (2006). Prosedur Penelitian Suatu Pendekatan Praktik.Jakarta: Rineka Cipta.

Sugiyono. (2008). Metode Penelitian Kuantitatif Kualitatif R\& D. Bandung: Alfabeta.

Widja, G. 1988. Pengantar Ilmu Sejarah: Sejarah dalam Perspektif Pendidikan.

Semarang: Satya Wacana. 
